\title{
THE DEVELOPMENT OF WEED VEGETATION IN THE PANNONIAN BASIN AS SEEN IN THE ARCHAEOBOTANICAL RECORDS
}

\author{
PÓSA, P. ${ }^{1 *}-$ VINOGRADOV, S. $^{2}-$ GYULAI, F. ${ }^{1}$ \\ ${ }^{1}$ Szent István University, Institute of Nature Conservation and Landscape Management \\ 2100 Gödöllö, Páter K. u. 1., Hungary \\ ${ }^{2}$ Szent István University, Department of Economics, Law and Methodology, \\ 2100 Gödöllö, Páter K. u. 1., Hungary \\ ${ }^{*}$ Corresponding author \\ e-mail: posapatricia@gmail.com \\ (Received 22 $2^{\text {nd }}$ Jun 2020; accepted $16^{\text {th }}$ Sep 2020)
}

\begin{abstract}
Thanks to archaeobotanical investigations, we can now treat it as a fact that the territory of Hungary is one of the longest inhabited parts of Europe. The Pannonian Basin plays a bridging role in the spread of plant cultivation knowledge along the path leading from the Middle East to the Balkans. The relationship between cultivated plants as well as weeds has been determined by the lifestyles of the populations that have lived in the Pannonian Basin and local climatic conditions. The cultivation of several species of plants is only associated with a specific archaeological era or a specific culture. The populations that have lived here have always brought and grown their own cultivated plants with them when they moved into the area. The archaeobotanical research in Hungary reaches back more than 140 years. During this long period of time 50 researchers were active in this topic and about 400 archaeological sites have been processed. Near 10 million seeds of 700 plant taxa (mostly species) were identified in the Pannonian Basin. Our catalogue of the weed remains from Hungarian excavations, indicates species and number of items, is classified on the basis of periods and sites, and ranges from the Neolithic to the Late Middle Ages.
\end{abstract}

Keywords: excavation, archaeophyton, Carpathian Basin, ecology, plant cultivation

\section{Introduction}

The study of prehistoric and historic weeds is an important topic of archaeobotany. Many attempts are made to match existing archaeobotanical data with the known agricultural systems of different archaeological eras. Küster (1985) was one of the forerunners who dealt with the distribution and origin of cereal weeds (Secalietea). Based on Rademacher (1968), and Willerding (1986) distinguished five different phases of weed flora development. Almost at the same time Knörzer (1984) described the prehistoric weed association of the North Rhein region under the botanical term Bromo-Lapsanetum praehistoricum. Recently, Frumin (2013, 2015, 2017) - partly based on Pysek's results (2002) - proposed an evaluation criterion for archaeobotanical weed records.

The ecological evaluation of weed species is based on the adaptation of ecological indicator values published in Raunkiaer's lifestyle system (1934). This was later re-introduced by Ellenberger et al. (1991). The so-called area classification evaluation system was developed by Ehrendorfer (1973) and further improved later on by Oberdorfer (1983).

The terms thanatocoenology and thanatocoenosys were created by Willerding (1983) based on the analysis of the ecological properties of weed remains recovered from 
various excavations. Later on Jacomet et al. (1989) recommended a metric evaluation system of the possible habitats instead of attempting to reconstruct once existing plant associations. The so called 'comprehensive weed history method' turned out to be an important and significant approach to understanding the agricultural development of archaeological cultures (Willerding, 1986; Jacomet et al., 1989; Kreuz et al., 2005; Kreuz and Schäfer, 2011).

In Hungary, the history of weed association development studies was written by herbologists and ecologist. Identification guides that were compiled in the last century also dealt with the dispersion of weed species. The works of Schermann (1966), Hunyadi (1988), Radics (1998), and Hunyadi et al. (2000) have to be mentioned among others. The ecological history and recent distribution of weeds within the Pannonian Basin has always been a significant issue and was dealt by numerous scholars such as Ubrizsy (1955), Ujvárosi (1957, 1973), Czimber (1987), Bartha (2000), Csontos (2001), Priszter (1997), Dancza (2011), and Lehoczky et al. (2013).

Weed associations were identified and described by Soó (1964-1985) and Borhidi et al. (2012). Based on the works of Ujvárosi (1952), Kárpáti et al. (1968), Soó (1973), Horváth et al. (1995), and Borhidi (1995) the so called life-form classification system and scale of Hungarian weed flora was also developed; a system aiming at the numerical and ecological analysis of weed associations.

The problems of apophytes (native species), archaeophytes (non-native, arriving before the $15^{\text {th }}$ century) and neophytes (non-native, arriving after the $15^{\text {th }}$ century) within the Pannonian Basin was first addressed by Terpó et al. (1999), Pinke and Pál (2005), Botta-Dukát and Balogh (2008), Balogh and Gyulai (2014) as well as by Henn et al. (2014) later on.

The study of invasive plants falls also within the issues of weed studies (Mihályi and Botta-Dukát, 2004). Processes of synanthropisation and anthropogenic effects influencing landscape changes were studied by Terpó (2000) and Pinke et al. (2011). Grouping of synanthropic plant species of different archaeological eras was done by Berzsényi (2000). Due to the effects of intensive agriculture many of the archaeophyton species are endangered by extinction in the Pannonian Basin today. For this reason, their examination also falls within the interest of historical agro-biodiversity research. A few of the adventive weeds are already on the list of protected and endangered plant species of Hungary (Udvardy, 2000).

In comparison to the above mentioned works, only very few studies dealt with the history, dispersion and development of weed species from an archaeobotanical perspective (Füzes, 1990; Gyulai et al., 1992; Berzsényi, 2000; Gyulai et al., 2013; Gyulai and Lakatos, 2013; Kenéz, 2014; Pósa et al., 2015). The basis of these is a catalogue of the weed finds sorted according to cultures and taxa, which was first compiled by Hartyányi et al. (1968, 1974), and later on improved by Gyulai (2010).

\section{Materials and methods}

\section{The archaeobotanical record}

Since the beginning of archaeological research (1860) in Hungary, nearly 50,000 sites were found. Out of these, 414 sites $(1 \%)$ have been studied from an archaeobotanical aspect (Fig. 1). Most settlements are known to be from the Middle Neolithic (55 sites), the Roman Age (53 sites), and the Late Middle Ages (37 sites) (Fig. 2). Our research is based on the supplemented and updated archaeobotanical 
dataset compiled by Gyulai (2010). This is a catalogue consisting of the seed, fruit, food and beverage remains from Hungarian excavations, indicating species and number of items, classified on the basis of periods and sites, ranging from the Neolithic to the Modern Ages, from the beginning of archaeobotanical research, up to the present, and in a chart form.
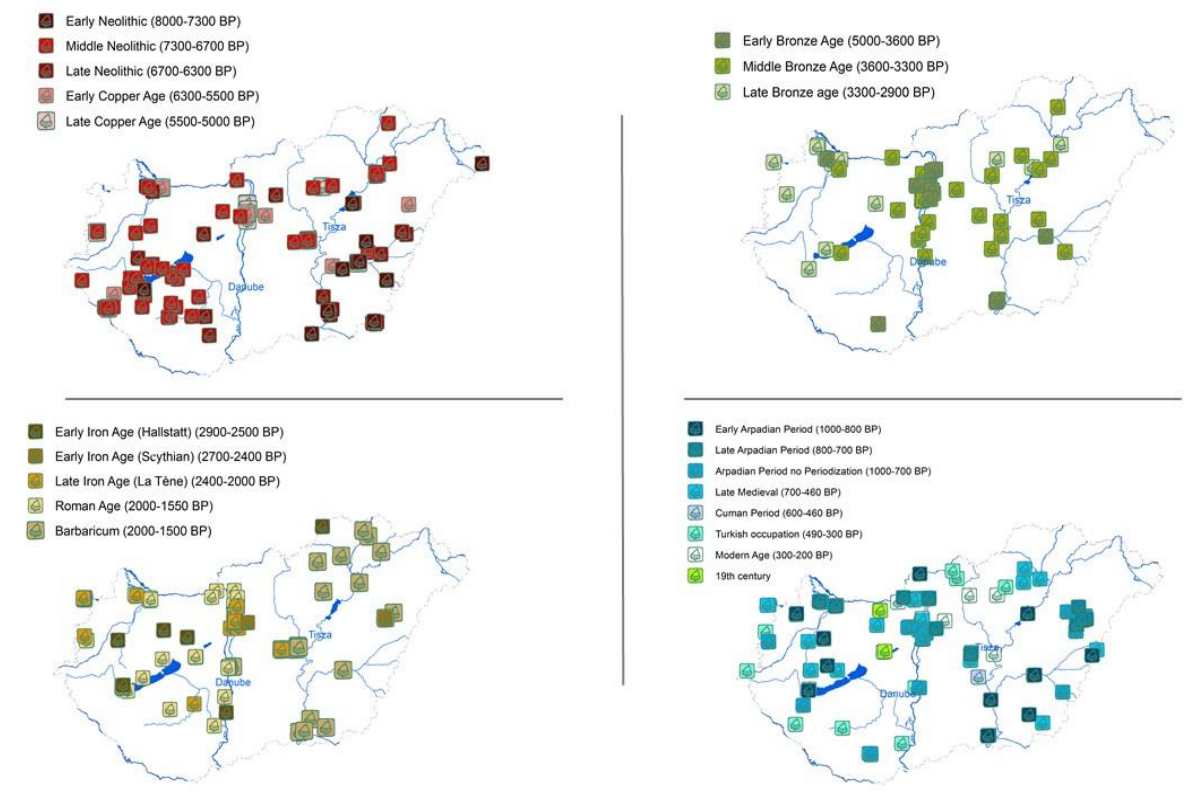

Figure 1. Map of the archaeological sites in Hungary

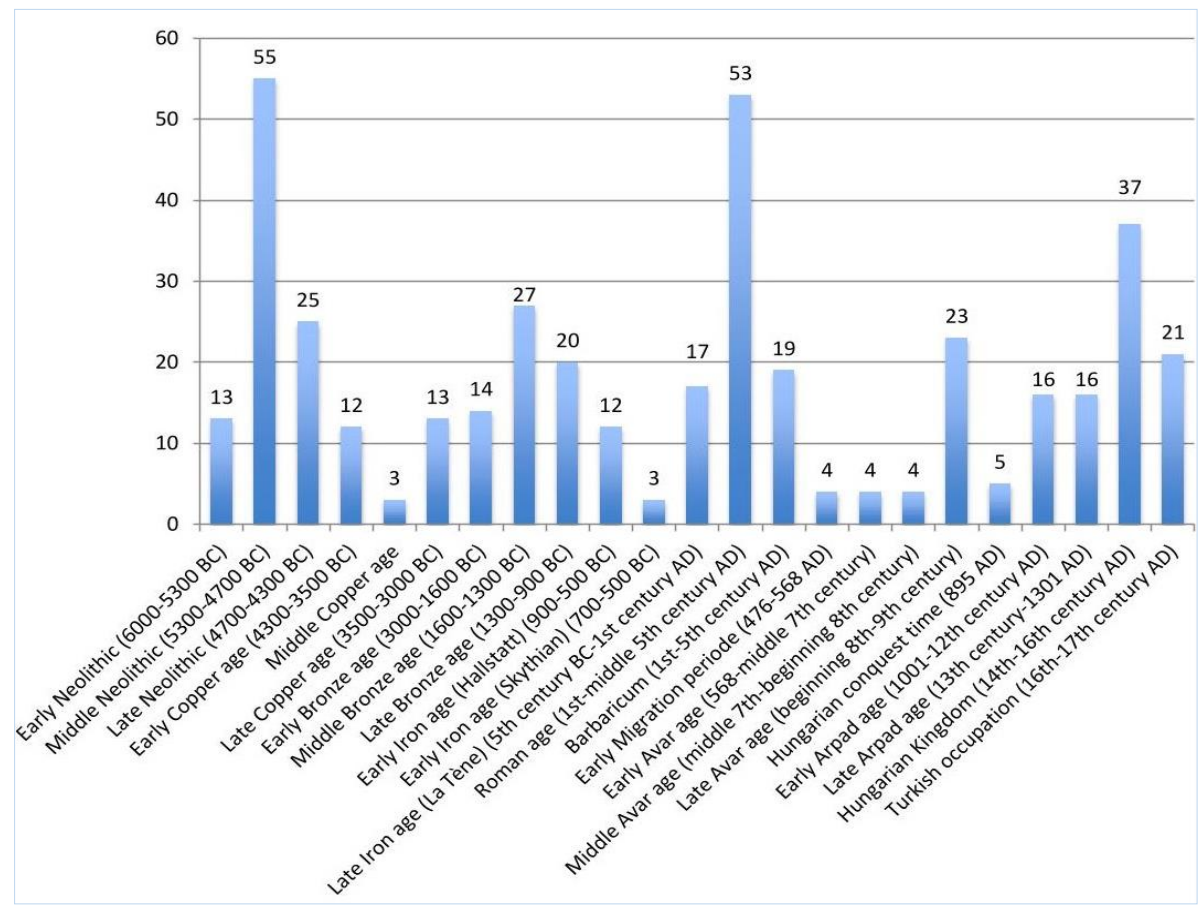

Figure 2. Number of archaeological sites in every archaeological era, at which archaeobotanical analysis was carried out 


\section{Methodological considerations}

The research dataset was completed by the selection of weeds, based on the identification criteria published earlier by Jacomet et al. (1989). This resulted in the list of weed species according to archaeological periods. The weed species have been classified as follows: cereal weeds, root- or summer crop weeds and ruderal weeds. The database has been expanded with additional data: type of area, life-form, residence time status (apophyte, archaeophyte, neophyte) and height (low, medium, high). In the list of weed species, a value of '1' was assigned to species which were present in the archaeological period, whereas ' 0 ' means they weren't present. In case a weed was present in multiple periods, all instances were assigned a '1', since if we didn't, our results would've been deformed. Analysing the huge data set was conducted using the IBM SPSS Statistics 22.0 software. The statistical analysis encompassed the following:

- Relationship between cereals and cereal weeds.

- Fluctuation of cereal weed species.

- Distribution of cereal weed species, depending on if they are present in the latest age or not, regarding first appearance.

- Distribution of cereal weed species by plant height, first appearance.

- Distribution of cereal weed species by life form, first appearance.

- Distribution of cereal weed species by area.

\section{Results}

The distribution of the plant species broken down to the archaeological eras of the Pannonian Basin gives us an overview of when the number of weeds increased throughout the history of the geographical area. The periods of increase of weed species: Middle Neolithic, Middle Bronze age, Roman age, Late Middle Ages (Fig. 3).

It is interesting to note that the number of weed species of the settled nomadic cultures with steppe origins coming from the east (Middle Copper age, Scythians, Sarmatians, Avars, Hungarians) was always higher than in the previous period. Some segetal weeds (e.g. Agrostemma githago, Bromus sp.) arrived with Neolithic farmers from the south-east, who later migrated slowly towards the west accompanied by indigenous species of Central and Eastern Europe.

\section{Distribution of cultivated and weed species}

Together with the rising number of cultivated species the diversity of weeds grew as well (Fig. 4).

However, there is no significant difference in the proportion of cereal weed, root- or summer crop weed and ruderal weed species during the different periods. Although the typical process is growth, yet in some age to fall: Copper Age, Early Bronze Age, Migration Period. In our opinion, the separation of winter- and summer crop weeds was not realised in the Pannonian Basin; they arrived into this separated geographical area in with their original ecological 'faith'.

The increasing number of ruderal species may be closely related to the rising number of settlements in certain periods. At the beginning of the Neolithic era (e.g. Körös culture), new, foreign species associated with plant cultivation appeared in the landscape. At the beginning of cereal cultivation, einkorn wheat, emmer wheat and barley were the characteristic cereals with shorter growth-cycle common millet was 
added in the Bronze Age. Both cultivated and wild ones also arrived, primarily from Asia Minor and the Mediterranean, and to a lesser extent from Asia. These had lived in association with domesticated plants, often as wild relatives of domesticates in their places of origin. But, in a cultivated context, they were simply weeds. The first segetal associations of the Neolithic and the Bronze Age had relatively high number of species, much higher than expected. According to archaeological plant material, white goosefoot (Chenopodium album) was present in very large quantities, while Avena fatua, Bromus arvensis, B. secalinus, Chenopodium hybridum, Fallopia convolvulus, Galium spurium, Vicia angustifolia were also common. In the Roman age several new segetal species appeared: Abutilon theophrasti, Anthemis cotula, Bifora radians, Centaurea cyanus, Cynodon dactilon, Diplotaxis muralis, Lathyrus hirsutus, Lepidium draba, Myagrum perfoliatum, Myosotis arvensis, Torilis arvensis, Vicia villosa. In the Middle and in the early Modern Age the weed flora enriched with new species, in which grain trade also played a role: Alopecurus myosuroides, Amaranthus retroflexus, Euphorbia exigua, Galeopsis tetrahit, Lepidium perfoliatum, Ranunculus sardous, Silene noctiflora, Vaccaria pyramidata, Valerianella carinata.

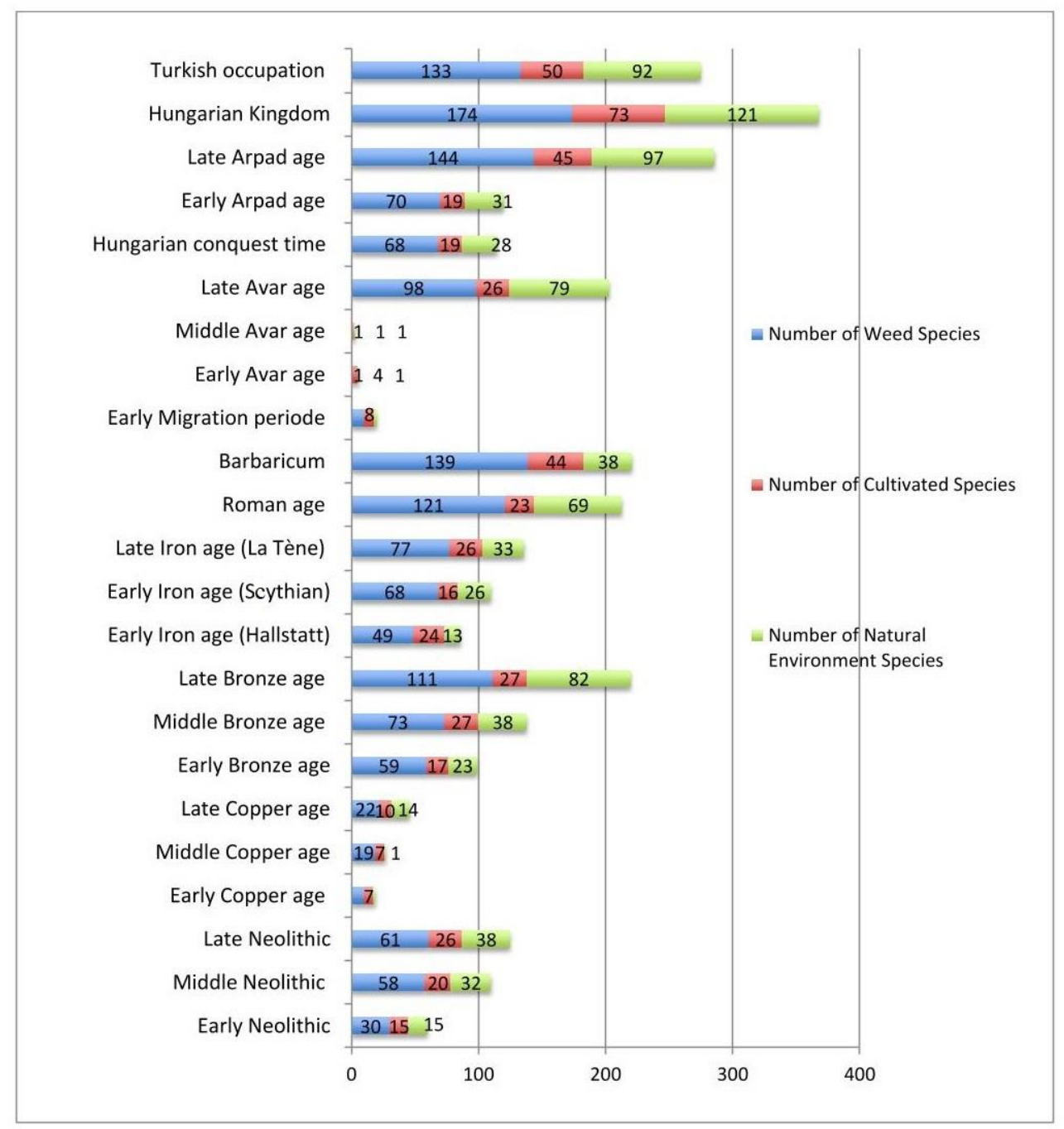

Figure 3. The number of weed, cultivated and natural environment plant species throughout the archaeological eras of the Carpathian Basin 


\begin{tabular}{|c|c|c|c|c|c|c|c|c|c|c|c|c|c|c|c|c|}
\hline & \begin{tabular}{|c|} 
Early \\
Neolithic \\
$(6000-5300$ \\
BC)
\end{tabular} & \begin{tabular}{|c|} 
Middle \\
Neolithic \\
$(5300-4700$ \\
BC)
\end{tabular} & $\begin{array}{c}\text { Late } \\
\text { Neolithic } \\
(4700-4300 \\
\text { BC) }\end{array}$ & $\begin{array}{c}\text { Eneol } \\
\text { Copper age } \\
(4300-3000 \\
\text { BC) }\end{array}$ & \begin{tabular}{|c|} 
Early Bronze \\
age \\
$(3000-1600$ \\
BC)
\end{tabular} & \begin{tabular}{|c|} 
Middle \\
Bronze age \\
$(1600-1300$ \\
BC)
\end{tabular} & \begin{tabular}{|c} 
Late \\
Bronze age \\
$(1300-900$ \\
BC)
\end{tabular} & $\begin{array}{c}\text { Early Iron } \\
\text { age } \\
(900-500 \\
\text { BC) }\end{array}$ & \begin{tabular}{|c} 
Late Iron aye \\
(La Tène) \\
(Sth century \\
BC-1st \\
century AD)
\end{tabular} & $\begin{array}{c}\text { Roman age } \\
\text { (1st-middle } \\
\text { 5th century } \\
\text { AD) }\end{array}$ & $\begin{array}{c}\text { Barbaricu } \\
m \text { (1st-Sth } \\
\text { century } \\
\text { AD) }\end{array}$ & $\begin{array}{c}\text { Migratio } \\
\text { n periode } \\
\text { (Sth-9h } \\
\text { century) }\end{array}$ & $\begin{array}{c}\text { Hung cong. } \\
\text { Early Arpad } \\
\text { age } \\
\text { (895-12th } \\
\text { century) }\end{array}$ & \begin{tabular}{|c|} 
Late Arpad \\
age (13th \\
century-130 \\
I AD) \\
\end{tabular} & \begin{tabular}{|c|} 
Late \\
medieva//Hu \\
ng. \\
Kingdom \\
(14th-16hth \\
century AD) \\
\end{tabular} & \begin{tabular}{|c|} 
Early New \\
Age/Turkish \\
occupation \\
(1526-17th \\
century AD) \\
\end{tabular} \\
\hline Number of cultivated species & 15 & 20 & 26 & 13 & 17 & 27 & 27 & 24 & 26 & 23 & 44 & 32 & 28 & 45 & 73 & 50 \\
\hline Number of cultivated seeds & 655 & 394918 & 476944 & 9573 & 2816 & 278687 & 159441 & 101339 & 10644 & 225212 & 232938 & 118180 & 367965 & 38835 & 3632970 & 241954 \\
\hline Number of cereal species & 12 & 12 & 12 & 9 & 10 & 13 & 12 & II & 12 & 13 & 13 & 10 & 10 & 13 & 13 & 10 \\
\hline Number of cereal grains & 644 & 394549 & 457496 & 9563 & 2806 & 253622 & 156806 & 101102 & 10402 & 218719 & 231847 & 115578 & 332292 & 37444 & 1728354 & 171661 \\
\hline $\begin{array}{l}\text { Number of cereal weed } \\
\text { species }\end{array}$ & 21 & 42 & 43 & 26 & 45 & 58 & 77 & 64 & 63 & 90 & 97 & 73 & 80 & 96 & 123 & 92 \\
\hline Number of cereal weed seeds & 203 & 3622 & 751 & 232320 & 272 & 39394 & 4480 & 5494 & 1327 & 5169 & 4792 & 141808 & 8774 & 80887 & 156471 & 89006 \\
\hline $\begin{array}{l}\text { Number of root-or summer } \\
\text { crop species }\end{array}$ & 3 & 8 & 12 & 4 & 7 & 13 & 14 & 10 & 11 & 6 & 15 & 11 & 13 & 17 & 30 & 21 \\
\hline $\begin{array}{l}\text { Number of root- or sunmer } \\
\text { crop weed species }\end{array}$ & 10 & 17 & 11 & 6 & 10 & 13 & 27 & 24 & 18 & 31 & 27 & 24 & 23 & 33 & 36 & 27 \\
\hline $\begin{array}{l}\text { Number of root- or summer } \\
\text { crop weed seeds }\end{array}$ & 64 & 3346 & 460 & 160 & 65 & 36988 & 3756 & 3816 & 942 & 3955 & 2276 & 140517 & 52874 & 75825 & 89864 & 5493 \\
\hline Number of ruderal species & 10 & 22 & 26 & 14 & 25 & 25 & 47 & 35 & 26 & 47 & 60 & 38 & 42 & 68 & 78 & 68 \\
\hline Number of ruderal seeds & 247 & 3234 & 470 & 179 & 57 & 37609 & 3695 & 3381 & 1058 & 24586 & 2338 & 140986 & 53385 & 90195 & 50526 & 241011 \\
\hline $\begin{array}{l}\text { Number of natural } \\
\text { environnent species }\end{array}$ & 15 & 32 & 38 & 16 & 23 & 38 & 82 & 48 & 33 & 69 & 38 & 86 & 82 & 97 & 121 & 92 \\
\hline $\begin{array}{l}\text { Number of natural } \\
\text { environment seeds }\end{array}$ & 395 & 175 & 1589 & 1786 & 116 & 185 & 3660 & 107 & 811 & 928 & 476 & 2401 & 987 & 2693 & 1538224 & 6568 \\
\hline
\end{tabular}

Figure 4. The most important data of the Hungarian Archaeobotanical Database

\section{Distribution of weed species by residence time status}

There is no significant difference between the proportion of apophytes and archaeophytes during the different archaeological eras (Fig. 5).

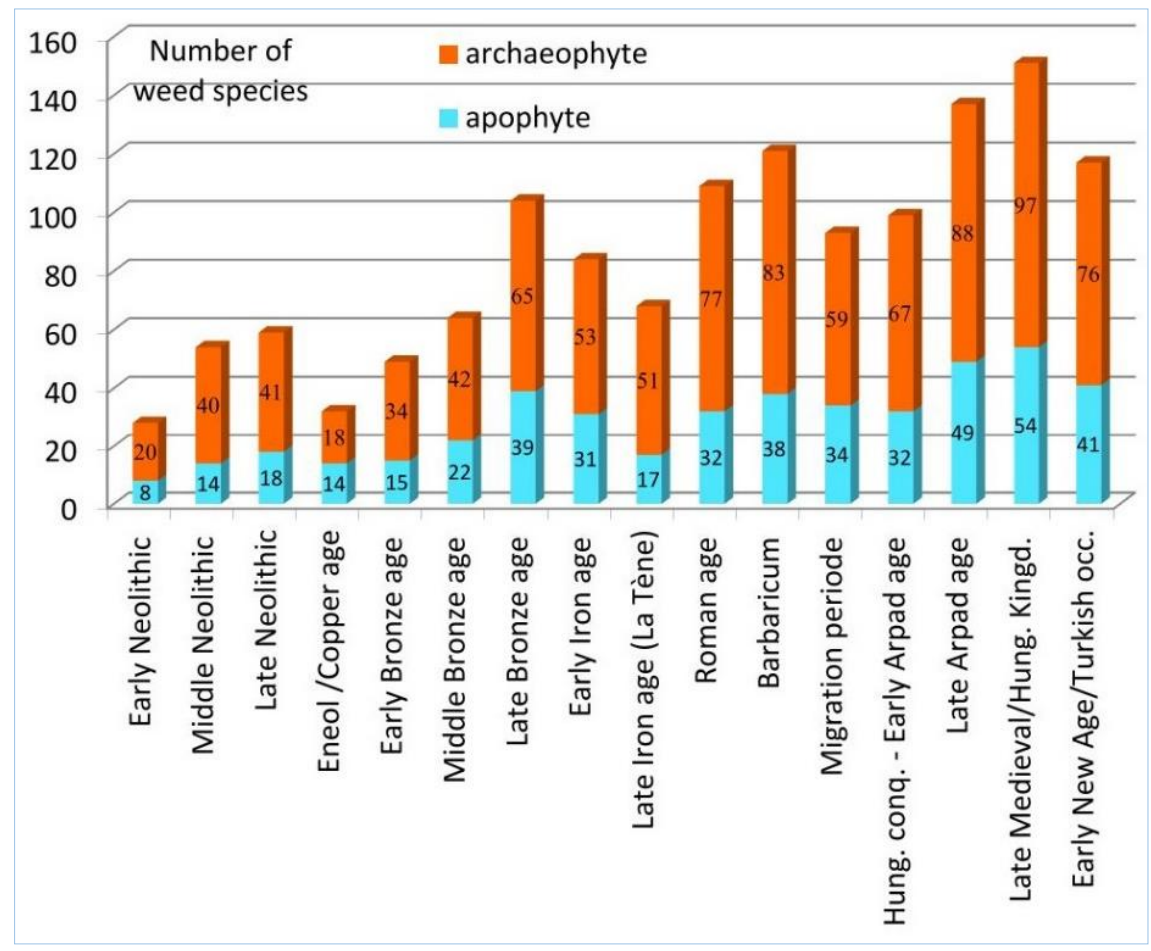

Figure 5. The number of archaeophyte and apophyte weed species throughout the archaeological era of the Carpathian Basin 
Until the Early Modern Age apophyte and archaeophyte species were dominant. However, there are terminological errors of their interpretation. When compared to western Europe, Bulgarian and Hungarian LBK species, five of them cannot be Hungarian apohytes because they also occurred in Bulgaria. So, the current division in other ages should also be reviewed. In addition to weeds introduced with sowing-seeds, elements of the previous flora were also present for some time. Domesticated species cultivated on arable land meant competition for the components of natural vegetation. Other plant species were less able to adapt to the changed conditions resulting from cultivation and subsequently disappeared. During the Middle and Late Neolithic period, a whole range of foreign weed species migrated to the central regions of Europe. Before AD 1500, the landscape was dominated by associations of archaeophytes and apophytes: archaeophytes: e.g. Agrostemma githago, Centaurea cyanus, Echinocloa crus-galli, Papaver rhoeas, Setaria pumila, Sinapis arvensis, Stachys annua, apophytes: Artemisia vulgaris, Agropyron repens, Centaurea cyanus, Consolida regalis, Digitaria sanguinea, Portulaca oleracea, Raphanus raphanistrum.

\section{Relationship among cereals and cereal weeds}

The number of cereal species in the Early Neolithic was higher than in later periods (Fig. 6). The existing cereal species were supplemented with new ones. In the latter two the high number of weeds may be related to manuring. In the beginning hulled wheats (einkorn wheat, emmer wheat) and naked barley, but later, after the Roman Age common wheat and rye were dominant. Until the Late Iron age, the number of cereal weed seeds were low compared to cereal grains. (Seed treatment was more effective perhaps?) The trend changed in the Roman Age. The number of cereal weed remains are many times higher than that of cereal grains. The number of weed species by winter cereals (einkorn wheat, emmer wheat, spelt, common wheat, dwarf wheat) and rye was proportionally higher than that of hulled wheat.

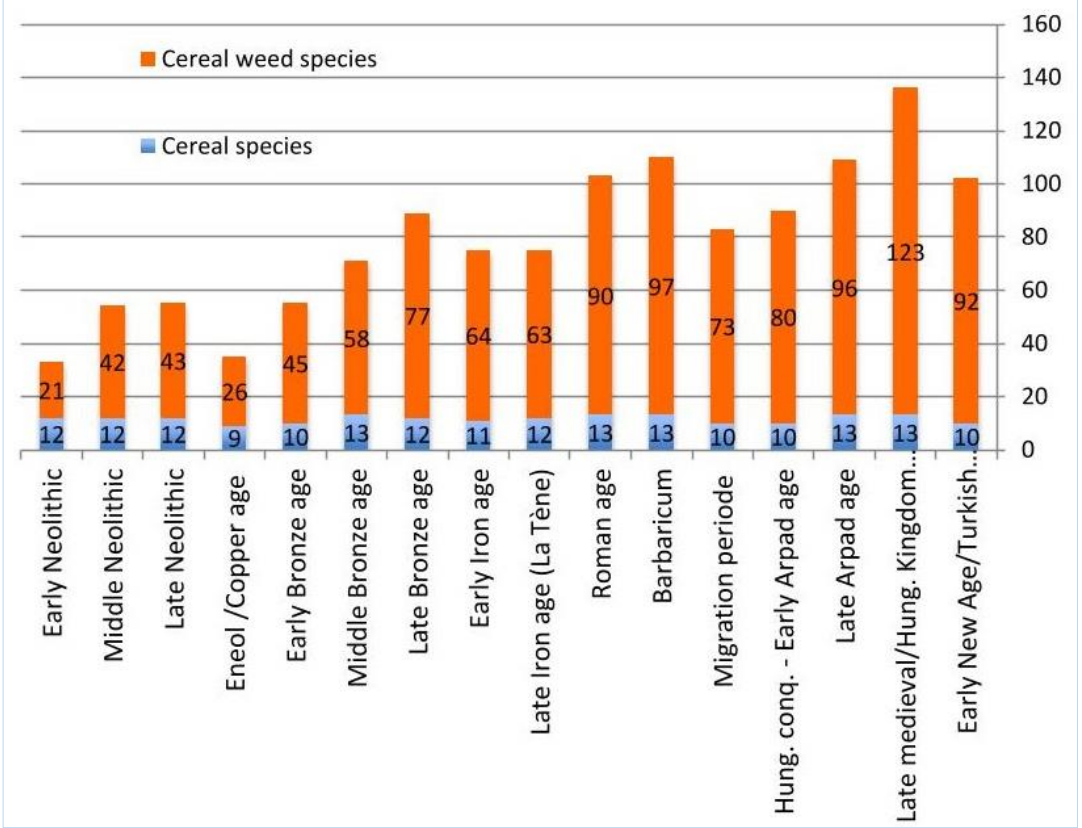

Figure 6. The relation between cereal and cereal weed species throughout archaeological eras of the Carpathian Basin 
The Neolithic, Bronze Age, Roman Age/Barbaricum and Late Middle Ages were the periods when most cereal weed species appeared (Fig. 7). Many cereal weed species disappeared in the Roman period (7) and even more in late Middle Ages (50!). In the Roman Age and late Medieval period, the weed flora changed thoroughly. Why? Both periods saw the use of ploughshare and manuring (Fig. 8).

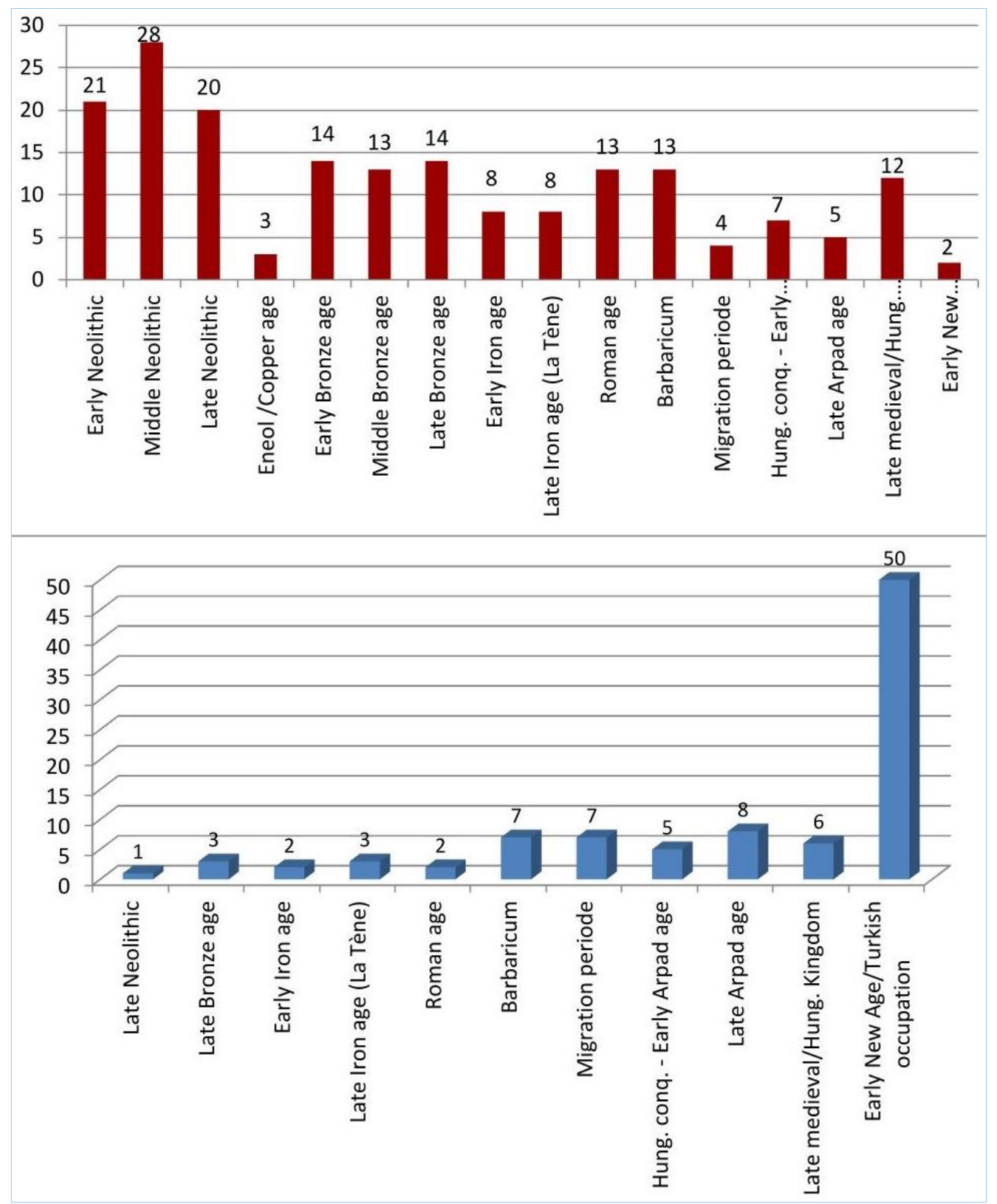

Figure 7. The number of appearing (above) and disappearing (below) weed species within the archaeological eras of the Carpathian Basin

\section{Distribution of cereal weed species by plant height in first appearance}

The presence of cereal weeds allows us to infer the time of sowing and the method of cultivation of cereals and the method of harvesting (high or low, with a sickle or with a scythe). Distribution of cereal weeds by height suggests that from the beginning until 
Late Middle Ages the use of sickle for harvesting was common. Dominant are the medium, medium/high and high species (Fig. 9). They are mostly high weed plants, which indicates that cereals were harvested using a sickle, at about two-thirds of the height of stalks. In the Modern Age the new weeds are higher, therefore the harvesting method starts to change: from sickle to scythe. Of course, do not forget that the cereals were previously higher than they are today.

\begin{tabular}{|c|c|c|c|c|c|c|c|c|c|c|c|c|c|c|c|c|}
\hline & $\begin{array}{c}\text { Earty Noolihich } \\
(6000-5300 \\
\text { BC) }\end{array}$ & $\begin{array}{c}\text { Middle } \\
\text { Neolithie } \\
\text { (5s300-4700 } \\
\text { BC) }\end{array}$ & $\begin{array}{c}\text { Late Neodithice } \\
(4700-4300 \\
\text { BC) }\end{array}$ & $\begin{array}{c}\text { Eneol/Copper } \\
\text { age (4300-3000 } \\
\text { BC) }\end{array}$ & \begin{tabular}{|c|} 
Earity Bronze \\
age \\
$(3000-1600$ \\
BC) \\
BC)
\end{tabular} & \begin{tabular}{|c|} 
Middle \\
Bronaze age \\
(16000-1300 \\
BC)
\end{tabular} & $\begin{array}{c}\text { Late Bronze } \\
\text { age (1300-900 } \\
\text { BC) }\end{array}$ & $\begin{array}{c}\text { Early Iron } \\
\text { age (900-500 } \\
\text { BC) }\end{array}$ & 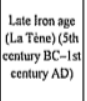 & $\begin{array}{c}\text { Roman age } \\
\text { (1st-middle } \\
\text { Sth hentury } \\
\text { AD) }\end{array}$ & $\mid \begin{array}{c}\text { Bastbricum } \\
\text { (Ist-sh } \\
\text { century } \\
\text { AD) }\end{array}$ & $\begin{array}{l}\text { Migration } \\
\text { periode } \\
\text { (Shh-9hth } \\
\text { century) }\end{array}$ & $\begin{array}{c}\text { Hunge conq, - } \\
\text { Early Arpad } \\
\text { age (895-12th } \\
\text { century) }\end{array}$ & $\begin{array}{l}\text { Late Appod age } \\
\text { (13th } \\
\text { century-1301 } \\
\text { AD) }\end{array}$ & $\begin{array}{c}\text { Late } \\
\text { medieval/Hung } \\
\text { Kingsom } \\
\text { (14th-16th } \\
\text { century AD) }\end{array}$ & $\begin{array}{c}\text { Early New } \\
\text { AgerTurkish } \\
\text { occepation } \\
\text { (1526-17th } \\
\text { eentury AD) }\end{array}$ \\
\hline Climale phase & Borcal/Atantic & Allantic & Allantic & Allantic & Subboreal & Subboreal & Subborcal & Subboreal & Subatlantic & Subatlantic & Subatalantic & Subatlantic & Suballantic & Subatlantic & Subutlantic & Subatlantic \\
\hline $\begin{array}{l}\text { Number of } \\
\text { sellements }\end{array}$ & 13 & ss & 25 & 28 & 14 & 27 & 20 & 15 & 17 & 53 & 19 & 35 & 19 & 16 & 37 & 21 \\
\hline $\begin{array}{l}\text { Number of } \\
\text { Culture }\end{array}$ & 1 & 6 & 3 & 6 & 3 & 7 & 4 & 2 & 1 & 1 & 1 & 5 & 1 & 1 & 1 & 2 \\
\hline Cullure & $\begin{array}{l}\text { Korós. } \\
\text { Starevevo }\end{array}$ & 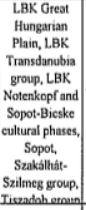 & $\begin{array}{c}\text { Tisza, Heppily. } \\
\text { Lengyel } \\
\\
\end{array}$ & $\begin{array}{c}\text { Bodrogkeresztür, } \\
\text { Baloton-Lasinija, } \\
\text { Ludaniec, } \\
\text { Protoboleriz, } \\
\text { Boleriz, Baden }\end{array}$ & $\begin{array}{c}\text { Bell Beaker, } \\
\text { Somogyvar. } \\
\text { Vinkovei, } \\
\text { Makó }\end{array}$ & 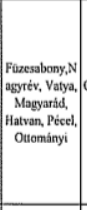 & 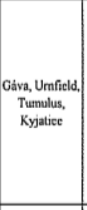 & $\begin{array}{l}\text { Hallstath, } \\
\text { Shythian }\end{array}$ & $\begin{array}{l}\text { Lat Tèe } \\
\text { (Celie) }\end{array}$ & Roman & Sarmatian & $\begin{array}{c}\text { Gepid, } \\
\text { Longobard, } \\
\text { German, varr. } \\
\text { Slav }\end{array}$ & Hungarian & Hungarian & Hungarian & $\begin{array}{c}\text { Hungerain, } \\
\text { Turks }\end{array}$ \\
\hline Mode of life & settled & settled & settled & $\begin{array}{c}\text { wandering } \\
\text { livestocksentled } \\
\end{array}$ & settled & settled & settled & \begin{tabular}{|c|} 
settled, \\
settled nermad
\end{tabular} & settled & settled & $\begin{array}{c}\text { settled } \\
\text { nomad }\end{array}$ & $\begin{array}{c}\text { nomads sertled } \\
\text { nomad }\end{array}$ & setled & settled & settled & settled \\
\hline Land use & 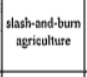 & 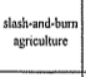 & 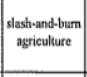 & $\begin{array}{c}\text { slasth-and-burm } \\
\text { agriciulurere }\end{array}$ & $\begin{array}{c}\text { slash-and-bum } \\
\text { agrieulture }\end{array}$ & $\left|\begin{array}{l}\text { not costrolled } \\
\text { fallow change }\end{array}\right|$ & $\mid$\begin{tabular}{|c|c|}
$\begin{array}{c}\text { not controlled } \\
\text { fallow change }\end{array}$ \\
$\mid$
\end{tabular} & \begin{tabular}{|} 
not tontrolled \\
fallow change
\end{tabular} & \begin{tabular}{|l|}
$\begin{array}{c}\text { not controlled } \\
\text { fallow change }\end{array}$ \\
\end{tabular} & $\begin{array}{c}\text { controlled } \\
\text { fallowow change } \\
+ \text { manuring }\end{array}$ & \begin{tabular}{|c} 
not \\
controlled \\
fallow \\
change \\
\end{tabular} & \begin{tabular}{|l} 
not controlled \\
fallow cthange
\end{tabular} & $\begin{array}{c}\text { controlled } \\
\text { fallow change } \\
\text { fat }\end{array}$ & \begin{tabular}{|c|} 
centrolled \\
fallow change
\end{tabular} & $\begin{array}{l}\text { conltoolled } \\
\text { fallow change }\end{array}$ & $\begin{array}{c}\text { two-ficld } \\
\text { rotation }+ \\
\text { matiouring }\end{array}$ \\
\hline $\begin{array}{l}\text { Soil tilage } \\
\text { equipment }\end{array}$ & digging stick & $\begin{array}{c}\text { digging plow } \\
\text { (ralolo)? }\end{array}$ & $\begin{array}{c}\text { digging plow } \\
\text { (rnalor) }\end{array}$ & $\begin{array}{c}\text { diggenin plow } \\
\text { (ralo) ?? }\end{array}$ & $\begin{array}{c}\text { digging plow } \\
\text { (ralo) }\end{array}$ & $\mid \begin{array}{c}\text { digging plow } \\
\text { (ralo) }\end{array}$ & \begin{tabular}{|l|}
$\substack{\text { digging plow } \\
\text { (ralo) }}$ \\
\end{tabular} & $\underset{\text { (ainging plow }}{\text { (ralo) }}$ & \begin{tabular}{|} 
digging plow \\
(fralo) whth iron \\
slippers
\end{tabular} & $\begin{array}{c}\text { single-sided } \\
\text { plow with iron } \\
\text { slippers }\end{array}$ & \begin{tabular}{|l|} 
digging \\
plow (ralo) \\
\end{tabular} & \begin{tabular}{|} 
digging plow \\
(ralo) with iron \\
slippers
\end{tabular} & $\begin{array}{c}\text { singles-sided } \\
\text { plow whth iron } \\
\text { slippers }\end{array}$ & \begin{tabular}{|} 
single-sided \\
plow with ion \\
slippers
\end{tabular} & \begin{tabular}{|l|} 
single-sided \\
plow with \\
ploughthare
\end{tabular} & $\begin{array}{l}\text { singlesided } \\
\text { plow with } \\
\text { ploughhhare }\end{array}$ \\
\hline Harvest & $\begin{array}{c}\text { wilh hand, } \\
\text { prinitive } \\
\text { sicklehturvest } \\
\text { knife }\end{array}$ & 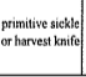 & $\begin{array}{c}\text { primative } \\
\text { sickletharvest } \\
\text { knife }\end{array}$ & $\begin{array}{l}\text { prinitive sickle } \\
\text { or harvest knife }\end{array}$ & $\begin{array}{c}\text { primitive sickle } \\
\text { or harvest } \\
\text { knife }\end{array}$ & bronze sickle & bronze sickle & sickle & iron sickle & $\begin{array}{l}\text { serrated or } \\
\text { "loothed" iron } \\
\text { sickle }\end{array}$ & sickle & $\begin{array}{c}\text { curved and } \\
\text { hooked sickle }\end{array}$ & $\begin{array}{c}\text { curved and } \\
\text { hooked sickle }\end{array}$ & \begin{tabular}{|l} 
curved dnd \\
hooked sickle
\end{tabular} & $\begin{array}{c}\text { curved dand } \\
\text { hooked sickle }\end{array}$ & $\begin{array}{l}\text { curved and } \\
\text { looked sickle } \\
\text { t seythe }\end{array}$ \\
\hline
\end{tabular}

Figure 8. Land use, harvest and other important data of the Hungarian Archaebotanical Database

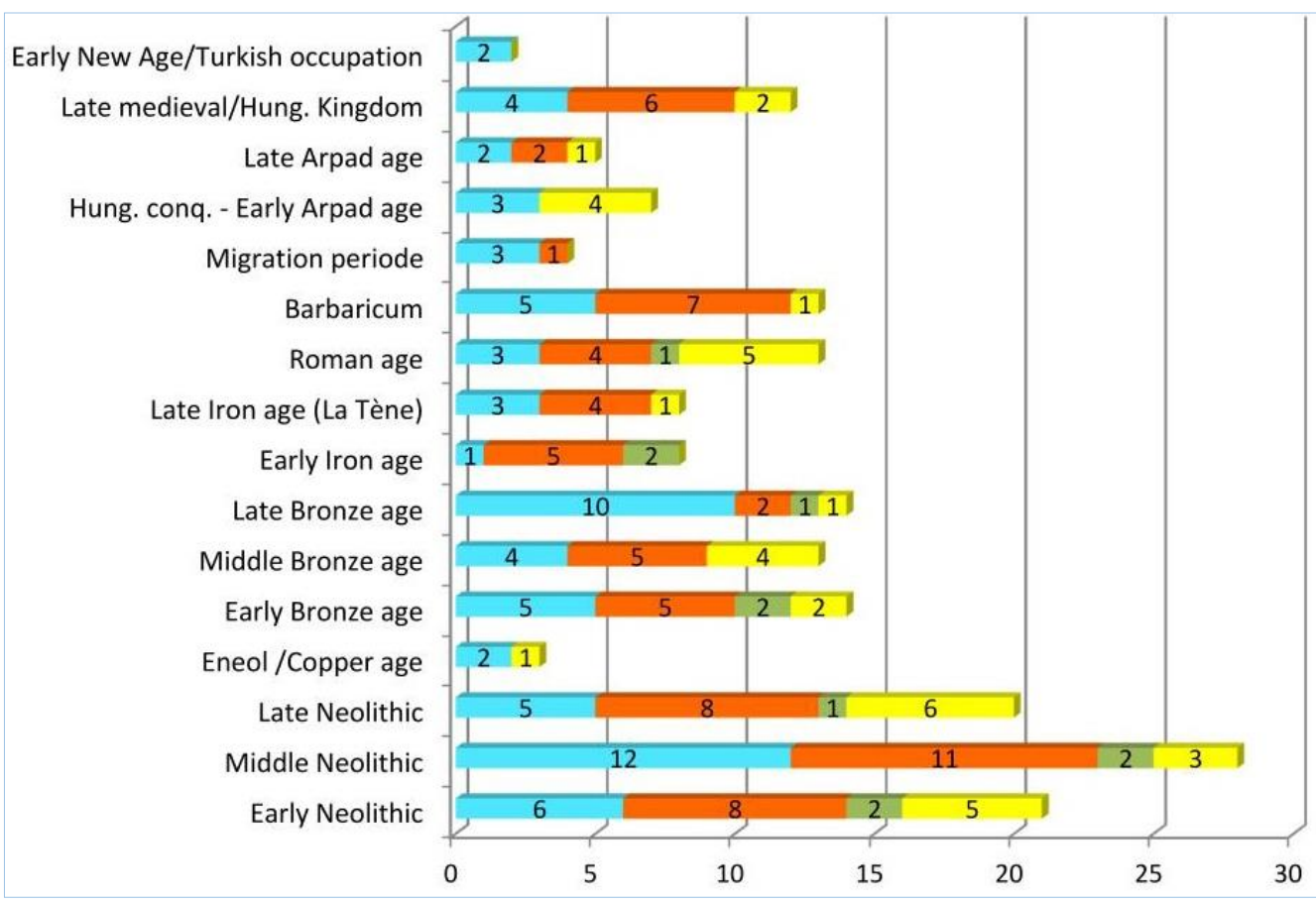

Figure 9. Distribution of cereal weed species by plant height and first appearance 


\section{Discussion and conclusions}

The up-to-date archaeobotanical database of Hungary contains the results of each known archaeological site, which was studied from an archaeobotanical point of view. Regardless of their publication the database contains all accessible data. This database, which provides an overview of the archaeobotanical results from 186 onwards was the basis of the present study, in which we analysed the development of weeds in the Pannonian Basin. Not only the list, but the changes in the appearance of apophyte and archaeophyte species was also compiled. The weed species were sorted according to height, by life form and by distribution area.

The appearance of weeds is connected to certain archaeological ears and phases: Early and Middle Neolithic, Middle Bronze age, Roman age, Late Medieval. This overlaps with the expansion of harvested species and a connection between the harvested and weed flora is emphasised.

The earliest dominant weed species in the Neolithic are: Agrostemma githago, Avane fatua, Bromus arvensis, Bromus secalinus, Chenopodium album, Fallopia convolvulus, Galium spurium. The most widespread and dominant seven weed species of the Pannonian Basin were studied.

The examination of the weeds according to their height shows that the ratio of medium and high species does not change from the beginning (Neolithic), which suggests that sickle was used until the Early Middle Ages to harvest cereals. Scythe was probably only used for harvesting later on.

No significant change can be detected in the ratio of the apophytes and the archaeophytes over time.

The fluctuation in the area-based distribution of the weed species is high. The strong Mediterranean effect in the Neolithic decrease by time and the number of Eurasian and Circumpolar species increases.

The species composition and the change of the number of the cereal weeds is related to land management practices (e.g. use of plow), soil fertilising techniques (e.g. manuring) and with the increase of the level of arable crop production.

The weeds of autumn- and spring-sown cereals already separated at the beginning of the Neolithic. This ecological separation already appeared outside the Pannonian Basin. At the beginning the presence of winter crop weed species was higher, but with the appearance of the leguminous plants in the Bronze Age and the garden species in the Late Middle Ages, the significance of summer crop weeds or row crop weeds increased.

\section{REFERENCES}

[1] Balogh. L., Gyulai, F. (2014): A magyarországi flóra ójövevénynövényei - előzetes jegyzék. - In: Balogh, L., Dancza, I., Király, G. (eds.) A magyarországi flóra jövevénynövényeinek jegyzéke. Szombathely, 2004. júl. 15. [Archaeophytes in the flora of Hungary - a preliminary list. Catalogue of alien plants of Hungary.]

[2] Bartha, D. (2000): A magyarországi dendroflóra adventive taxonjai. - Tilia (Sopron) 9: 232-240. [Adventive taxa of Hungarian dendroflora.]

[3] Berzsényi, B. (2000): A települési vegetáció keletkezése a régészeti-növénytani adatok alapján. - In: Füleki Gy. (ed.) A táj változásai a Kárpát-medencében a történelmi események hatására. Budapest-Gödöllö, 26-30. [Landscape changes in the Carpathian Basin.] 
[4] Borhidi, A. (1995): Social behaviour types, the naturalness and relative ecological indicator values of the higher plants in the Hungarian flora. - Acta Botanica Hungarica 39(1-2): 97-181.

[5] Borhidi, A., Kevey, B., Lendvai, G. (2012): Plant communities of Hungary. - Akadémiai Kiadó, Budapest, 544 p.

[6] Botta-Dukát, Z., Balogh, L. (eds.) (2008): The most important invasive plants in Hungary. - HAS IEB, Vácrátót, pp. 227-255.

[7] Czimber, Gy. (1987): A gyomnövényekröl napjainkban. - VEAB felolvasóülések, F/17: 17-32. [About weeds.]

[8] Csontos, P. (2001): A természetes magbank kutatásának módszerei. - Synbiologia Hungarica 4. Scientia, Budapest, 156 p. [Methods for studying soil seed banks.]

[9] Dancza, I. (ed.) (2011): Az Ötödik Országos Gyomfelvételezés Magyarország szántóföldjein. - Vidékfejlesztési Minisztérium, Budapest, 570 p. [The fith national weed survey in Hungary.]

[10] Ehrendorfer, F. (1973): Liste der Gefässpflanzen Mitteleuropas. - Stuttgart: Gustav Fischer Verlag, $318 \mathrm{p}$.

[11] Ellenberg, H., Weber, H. E., Düll, R., Wirth, V., Werner, W., Paulissen, D. (1991): Zeigerwerte von Pflanzen in Mitteleuropa. - Scripta Geobot 18: 1-248.

[12] Frumin, S., Maeir, A., Weiss, E. (2013): Weeds as an indicator for anthropogenetic links of the past. $-16^{\text {th }}$ Conference of the International Work Group for Palaeoethnobotany, Thessaloniki. Abstracts book, 40.

[13] Frumin, S., Maeir, A. M., Horwitz, L. K., Weiss, E. (2015): Studying ancient anthropogenic impacts on current floral biodiversity in the Southern Levant as reflected by the Philistine migration. - Scientific reports 5: 13308 .

[14] Frumin, S. (2017): Invasion Biology Analysis in Archaeobotany. - Philistines Culture at Tell eș - Șāfi/Gath as a Case Study, unpublished Ph.D. dissertation, Bar-Ilan University, Ramat-Gan.

[15] Füzes, M. (1990): A földmívelés kezdeti szakaszának (neolitikum és rézkor) növényleletei Magyarországon; Archaeobotanikai vázlat. - Tapolcai Városi Múzeum Közleményei 1: 139-238. [Plant remains from the early phase of plant cultivation Neolithic and Copper Age - in Hungary. An archaeobotanical outline.]

[16] Gyulai, F., Hertelendi, E., Szabó, I. (1992): Plant remains from the early medieval lakeshore settlement Fonyód-Bélatelep (Lake Balaton, Hungary) with especial emphasis on the history of fruit cultivation in Pannonia. - Vegetation History and Archaeobotany 1: 177-184.

[17] Gyulai, F. (2010): Archaeobotany in Hungary. Seed, Fruit, Food and Beverages Remains in the Pannonian Basin: an Archaeobotanical Investigation of Plant Cultivation and Ecology from the Neolithic until the Late Middle Ages. - Archaeolingua, Budapest, 479.

[18] Gyulai, F., Lakatos, B. (2013): La Tène archaeobotanical remains from KeszthelyFenékpuszta. - In: Heinrich-Tamáska, O. (ed.) Keszthely-Fenékpuszta: Katalog der Befunde und Ausgewählter Funde sowie neue Forschungsergebnisse. Castellum Pannonicum Pelsonense Vol. 3. Verlag Marie Leindorf GmbH, Budapest-LeipzigKeszthely-Rahden/Westf. 716.

[19] Gyulai, F., Emődi, A., Mravcsik, Z., Pósa, P. (2013): Az újkori mezőgazdasági kultúrkörnyezet rekonstrukciója a sárospataki ásatások példáján. - Gesta 13: 67-71. [Reconstruction of environment and history of plant use in Sárospatak.]

[20] Hartyányi, P. B., Nováki, Gy., Patay, Á. (1968): Növényi mag- és termésleletek Magyarországon az újkőkortól a XVIII. sz.-ig I. - Magyar Mezőgazdasági Múzeum Közleményei 1967-68: 5-85. [Archaeobotanical overview in Hungary from the Neolithic to the Modern Age I.]

[21] Hartyányi, P. B., Nováki, Gy. (1974): Növényi mag- és termésleletek Magyarországon az újkőkortól a XVIII. sz.-ig II. - Magyar Mezőgazdasági Múzeum Közleményei 1973-74: 23-73. [Archaeobotanical overview in Hungary from the Neolithic to the Modern Age II.] 
[22] Henn, T., Jacomet, S., Nagy, D. U., Pál, R. W. (2014): Desiccated diaspores from building materials: methodological aspects of processing mudbrick for archaeobotanical studies and first results of a study of earth buildings in southwest Hungary. - Vegetation History and Archaeobotany 24(3): 1-14.

[23] Horváth, F., Dobolyi, Z. K., Morschhauser, T., Lökös, L., Karas, L., Rédei, T. (1995): Flóra adatbázis 1.2. Taxon-lista és attribútum-állomány. - Flóra Munkacsoport, MTA ÖBKI és MTM Növénytára, Vácrátót-Budapest, 252. [Flora database.]

[24] Hunyadi, K. (1988): Szántóföldi gyomnövények és biológiájuk. - Mezőgazdasági Kiadó, Budapest, 483. [Weed species and their biology.]

[25] Hunyadi, K., Béres, I., Kazinczi, G. (eds.) (2000): Gyomnövények, gyombiológia, gyomirtás. - Mezőgazda Kiadó, Budapest, 630. [Weed species, their biology and control.]

[26] Jacomet, S., Brombacher, Ch., Dick, M. (1989): Archäobotanik am Zürichsee. Vol. 7. Berichte der Zürchweeder Denkmalpflege, Monographien. - Zürich: Orell Füssli, 348 p. [Archaeobotanical overview at Lake Zürich.]

[27] Kárpáti, I., Kárpáti, V., Borbély, Gy. (1968): Magyarországon elterjedt ruderális gyomnövények synökológiai besorolása. - A keszthelyi Agrártudományi Főiskola Közleményei 10: 1-40. [Classification of ruderal weed associations in Hungary.]

[28] Kenéz, Á. (2014): Keszthely-Fenékpuszta római kori régészeti-növénytani leleteinek feldolgozása, különös tekintettel az egykori környezeti állapot jellemzésére. - $\mathrm{PhD}$ értekezés. Gödöllő. [Archaeobotanical analysis in Keszthely-Fenékpuszta from the Late Roman period.]

[29] Knörzer, K. H. (1984): Veränderungen der Unkrautvegetation auf rheinischen Bauernhöfen seit der Römerzeit. - Bonner Jahrbücher 184: 479-503.

[30] Kreuz, A., Marinova, E., Schäfer, E., Wiethold, J. (2005): A comparison of early Neolithic crop and weed assemblages from the Linearbandkeramik and the Bulgarian Neolithic cultures: differences and similarities. - Vegetation History and Archaeobotany 14: 237-258.

[31] Kreuz, A., Schäfer, E. (2011): Weed finds as indicators for the cultivation regime of the early Neolithic Bandkeramik culture? - Vegetation History and Archaeobotany 20: 333348.

[32] Küster, H. (1985): Herkunft and Ausbreitungsgeschichte einiger Secalietea-Arten. Tüxenia 5: 89-98. [Origin and history of some Secalietea species.]

[33] Lehoczky, É., Gólya, G., Radimszky, L., Riczu, P., Tamás, J. (2013): Gyomflóra vizsgálatok trágyázási tartamkísérletben. - In: Janda, T. (ed.) II. ATK Tudományos Nap: Velünk Élő Tudomány. MTA Agrártudományi Kutatóközpont, 2013, 221-224. [Analysis of weed association.]

[34] Mihályi, B., Botta-Dukát, Z. (eds.) (2004): Özönnövények. - TermészetBúvár Alapítvány, Budapest, 408. [Invasive plant species.]

[35] Oberdorfer, E. (1983): Pflanzensoziologische Exkursionsflora. Fünfte, überarbeitete und ergänzte Auflage. - Ulmer, Stuttgart, 1051. [Plant sociological excursion flora for Germany.]

[36] Pinke, Gy., Pál, R. (2005): Gyomnövényeink eredete, termőhelye és védelme. Alexandra, Pécs, 232. [Origin, growing place, protection of weed species in Hungary.]

[37] Pinke, Gy., Király, G., Barina, Z., Mesterházy, A., Balogh, L., Csiky, J., Schmotzer, A., Molnár, A. V., Pál, R. W. (2011): Assessment of endangered synanthropic plants of Hungary with special attention to arable weeds. - Plant Biosystems 145(2): 426-435.

[38] Pósa, P., Emődi, A., Schellenberger, J., Hajdú, M., Mravcsik, Z., Gyulai, F. (2015): Előzetes jelentés Miskolc-Hejő melletti szkíta kori kút növényi maradványainak feldolgozásáról. - Gesta 13: 3-18. [Archaeobotanical analysis of an Iron Age well from Miskolc-Hejö.]

[39] Priszter, Sz. (1997): Research of the Hungarian adventive flora. - Botanikai Közlemények 84: 25-32. 
[40] Pyšek, P., Sádlo, J., Mandák, B. (2002): Catalogue of alien plants of the Czech Republic. - Preslia, Praha 74: 97-186.

[41] Rademacher, B. (1968): Gedanken zur Fortenwicklung der Unkrautforschung und Unkrautbekämpfung. - Z. f. Pflanzenkrankh. u. Pflanzenschutz, Sonderh. 4: 11-22. [Thoughts on the development of weed research and control.]

[42] Radics, L. (ed.) (1998): Gyommaghatározó. - Mezőgazda Kiadó, Budapest, 244. [A manual for the identification of weed seeds.]

[43] Raunkiær, C. (1934): The Life Forms of Plants and Statistical Plant Geography. - Oxford University Press, London.

[44] Schermann, Sz. (1966): Magismeret. - Akadémia Kiadó, Budapest. I: 208., II: 861. [Seed of knowledge.]

[45] Soó, R. (1964-1985): A magyar flóra és vegetáció rendszertani-növényföldrajzi kézikönyve. - Akadémiai Kiadó, Budapest. [Systematical and Geobotanical Handbook of Hungarian Flora and Vegetation I-VII.]

[46] Soó, R. (1973): A magyar flóra és vegetáció rendszertani-növényföldrajzi kézikönyve V. - Akadémiai Kiadó, Budapest, 723. [Systematical and Geobotanical Handbook of Hungarian Flora and Vegetation V.]

[47] Terpó, A., Zając, M., Zając, A. (1999): Provisional list of Hungarian archaeophytes. Thaiszia 9(1): 41-47.

[48] Terpó, A. (2000): A táj szinantropizációja a nagy történelmi sorsfordulók idején. - In: Füleki, Gy. (ed.) A táj változásai a Kárpát-medencében a történelmi események hatására. Budapest-Gödöllö. 18-25. [Landscape changes in the Carpathian Basin.]

[49] Ubrizsy, G. (1955): Magyarország ruderális gyomnövénytársulásai II. Ökológiai és szukcessziós tanulmányok. - Növénytermelés 4(2): 109-126. [Ruderal weed associations in Hungary II. Studies on ecology and succession.]

[50] Udvardy, L. (2000): Archaikus gabonagyomjaink, mint dísznövények. - In: Gyulai, F. (ed.) Az agrobiodiverzitás megőrzése és hasznosítása. Tápiószele, 424. [Weed species as ornamentals.]

[51] Ujvárosi, M. (1952): Szántóföldjeink gyomnövényfajai és életforma-analízisük. Növénytermelés 1952: 27-50. [Weed species of our arable fields and analysis of their lifeform.]

[52] Ujvárosi, M. (1957): Gyomnövények, gyomirtás. - Mezőgazdasági Kiadó, Budapest, 786. [Weed species, weed control.]

[53] Ujvárosi, M. (1973): Gyomnövények. - Mezőgazdasági Kiadó, Budapest, 833. [Weeds.]

[54] Willerding, U. (1983): Paläo-etnobotanische Befunde und schriftliche sowie ikonographische Zeugnisse in Zentraleuropa. Rotterdam. - Studies in palaeoetnobotany 5: 75-88. [Plants and Ancient Man.]

[55] Willerding, U. (1986): Zur Änderung der Unkrautflora und Unkrautvegetation in jüngster Zeit. - In: Zur Geschichte der Unkräuter Mitteleuropas. Wachholtz Verlag Neumünster, 382. [The changing of the weed association and vegetation.] 


\section{APPENDIX}

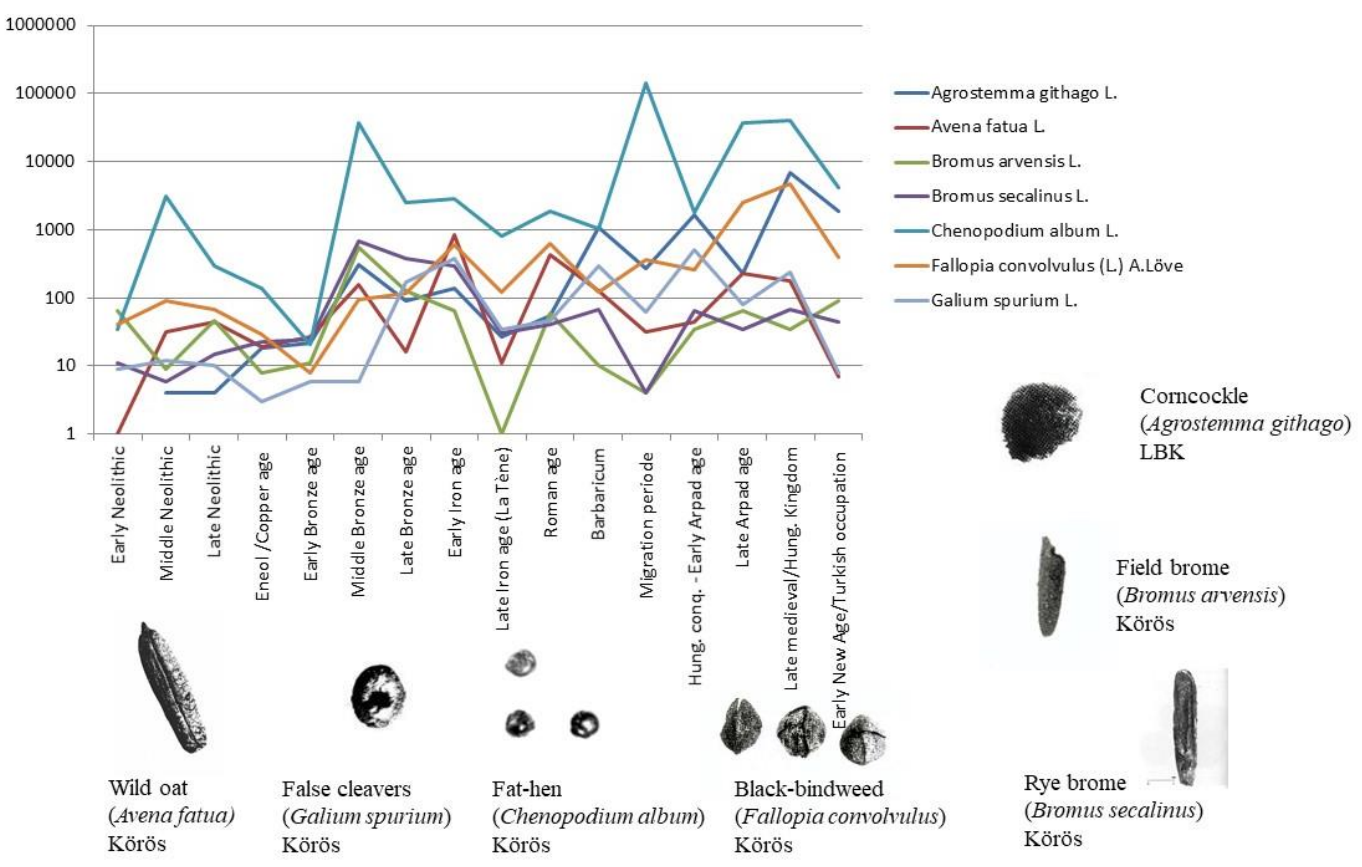

Appendix 1. Career of the "seven great evil". Number of grains in logarithmic distribution 